\title{
Two new feather mites of the genus Protonyssus Trouessart, 1916 (Acariformes: Xolalgidae) from Brazilian parakeets (Psittacidae), with a key to species
}

\section{Fabio Akashi Hernandes \& Luiz Gustavo A. Pedroso}

To cite this article: Fabio Akashi Hernandes \& Luiz Gustavo A. Pedroso (2017) Two new feather mites of the genus Protonyssus Trouessart, 1916 (Acariformes: Xolalgidae) from Brazilian parakeets (Psittacidae), with a key to species, International Journal of Acarology, 43:3, 204-211, DOI: 10.1080/01647954.2016.1250815

To link to this article: https://doi.org/10.1080/01647954.2016.1250815

曲 Published online: 06 Nov 2016.

Submit your article to this journal $[\pi$

ஹll Article views: 61

View Crossmark data [

Citing articles: 1 View citing articles ¿ 


\title{
Two new feather mites of the genus Protonyssus Trouessart, 1916 (Acariformes: Xolalgidae) from Brazilian parakeets (Psittacidae), with a key to species
}

\author{
Fabio Akashi Hernandes and Luiz Gustavo A. Pedroso \\ Departamento de Zoologia, Universidade Estadual Paulista, Rio Claro, São Paulo, Brazil
}

\section{ABSTRACT}

The feather mite genus Protonyssus Trouessart (Xolalgidae: Ingrassiinae) has included four species associated with Neotropical and Old World parrots. In this article, two new species are described from Brazilian parakeets: Protonyssus mironovi sp. nov. from Psittacara leucophthalmus (Statius Müller, 1776), and P. athoracicus sp. nov. from Brotogeris chiriri (Vieillot, 1818) (Psittaciformes: Psittacidae). A key to species of the genus Protonyssus is presented.

http://zoobank.org/urn:Isid:zoobank.org:pub:CE255F6D-014E-40BF-87DA-226C919F08CB

\section{ARTICLE HISTORY}

Received 6 September 2016 Accepted 14 October 2016 Published online 6 November 2016

\section{KEYWORDS}

Feather mites; Acari systematics; Psittacidae; ectoparasites; avian mites

\section{Introduction}

The family Xolalgidae (Acariformes: Analgoidea) - along with Analgidae and Psoroptoididae - is one of the three feather mite families that inhabit mostly the downy feathers of birds (Dabert and Mironov 1999). Xolalgids are generally characterized by a weak sclerotization of the idiosoma, femora and genua fused in all legs, only one ventral seta on tarsus III, seta $k T$ absent from tibia IV, and epimerites I fused into a sternum. The family comprises about 130 species in three subfamilies and 25 genera (Gaud and Atyeo 1981, 1996; Mironov 2004; Dabert et al. 2007), and is one of the most diverse concerning the host range, including birds from 17 orders, being the only feather mite family recorded from the order Sphenisciformes (penguins) (Gaud and Atyeo 1981; Mironov 2004; Mironov and Proctor 2008).

The subfamily Ingrassiinae (Gaud and Atyeo 1996) is the most diverse and associated with a much wider array of hosts in comparison with the Xolalginae and Zumptiinae. In Brazil, xolalgids are still poorly studied. In a checklist of feather mites of Brazil, Valim et al. (2011) listed only four species, being three from the Ingrassiinae and one Xolalginae; subsequently, five ingrassiines were described - one Hartingiella, two Analloptes, and two Gymnalloptes, from nightjars (Caprimulgidae), passerines (Conopophagidae, Tyrannidae), and hoatzins (Opisthocomidae), respectively (Hernandes 2014; Mironov and Hernandes 2014; Hernandes and Mironov 2015); Leptosphyra centropoda (Mégnin 1877), originally described from the northern lapwing Vanellus vanellus (Linnaeus) (Charadriidae), was reported from the southern lapwing, Vanellus chilensis (Molina) (Pedroso et al. 2015), and Ingrassia aequinoctialis (Trouessart, 1899), described from Phaethon aethereus Linnaeus, 1758 and $P$. rubricauda Boddaert 1783 was reported from $P$. lepturus Daudin, 1802 (Phaethontidae) (Hernandes et al. 2015). Undetermined species of Dubininia, Analloptes, and Xolalgoides were also reported from parrots (Psittacidae), jacamars (Galbulidae), and passerines (Furnariidae, Tyrannidae, Parulidae, and Vireonidae) of Brazil (Albuquerque et al. 2012; Enout et al. 2012; Silva et al. 2015).

Four xolalgid genera - all of which from the Ingrassiinae associate with parrots (Psittaciformes): Cacatualges Dabert et al. 2007, Dubininia Vassilev, 1958, Fainalges Gaud and Berla, 1964, and Protonyssus; Trouessart 1916.

In this article, we describe two new Protonyssus species from parakeets (Psittacidae) of Brazil. A key to species of this genus is presented.

\section{Materials and methods}

The material was retrieved from dead birds sent to the laboratory of Acari of São Paulo State University (UNESP), campus of Rio Claro, and kept in a freezer. Birds were washed and the liquid was filtered in paper filters; the mites were collected from the filters using a dissecting microscope, cleared in $30 \%$ lactic acid for $24 \mathrm{~h}$ at $50^{\circ} \mathrm{C}$, and mounted in Hoyer's medium according to the standard technique for small mites (Krantz and Walter 2009). After five days at $50^{\circ} \mathrm{C}$, the slides were sealed with varnish. Drawings and measuring of mites were made with a Leica DM3000 microscope equipped with differential interference contrast (DIC) optics and a camera lucida. Pencil sketches were scanned at 300 dpi grayscale and line drawings were created with Adobe Illustrator CS6 and a Wacom Bamboo Create tablet. Type specimens are deposited at DZUnesp-RC - Collection of Acari of Department of Zoology of the Universidade Estadual Paulista, Rio Claro, São Paulo, Brazil; ZISP - Zoological institute, Russian Academy of Sciences, Saint Petersburg, Russia; UMMZ - Museum of Zoology, the University of Michigan (Ann Arbor, USA); USNM National Insect and Mite Collection, National Museum of Natural History, Smithsonian Institution, located at the SEL-USDA, Beltsville, Maryland, USA; DZSJRP - Acari Collection of Departamento de Zoologia e Botânica of Universidade Estadual Paulista, São José do Rio Preto, São Paulo, Brazil. The chaetotaxy of the idiosoma and legs follows Griffiths et al. (1990) and Atyeo and Gaud (1990), respectively, with corrections for coxal setae proposed by Norton (1998). Measurements of particular structures are as described by Mironov et al. (2005).

\section{Xolalgidae Dubinin, 1953 \\ Ingrassiinae Gaud and Atyeo, 1981 \\ Protonyssus Trouessart, 1916}

Type species: Protalges larva Trouessart, 1885, by original designation.

The type species, Protalges larva, was originally described from several Neotropical hosts: "Ara macao, Amazona melanocephala [=Pionites melanocephalus (L.)], et autres perroquets de l'Amérique méridionale" (Trouessart 1885, p. 58). Upon erecting the genus Protonyssus, Trouessart (1916) elected P. larva from Brotogeris jugularis (Statius Müller, 1776) as the type species. Protonyssus integrifolius (Trouessart, 1885) was also described 
from various Neotropical psittacids: "Ara severus, Conurus cruentatus [=Pyrrhura cruentata], C. smaragdinus [=Enicognathus ferrugineus], Psittacula virescens [=Brotogeris versicolurus], de l'Amérique méridionale". The two additional Protonyssus species were each described from a single host species: Protonyssus brevis (Trouessart, 1885) from Psittacula lunulata (=Bolbopsittacus lunulatus, Psittaculidae) from the Philippines, and Protonyssus proctorae Mironov et al. 2005, from the extinct Conuropsis carolinensis, from North America (Trouessart 1885, 1916; Gaud 1980; Gaud and Atyeo 1981; Mironov et al. 2005). An undetermined species was recently reported from the two species of Enicognathus, E. ferrugineus (Statius Müller, 1776) and E. leptorhynchus (King, 1831) in Chile (Valdebenito et al. 2015).

The genus Protonyssus currently comprises six species, including the two new species described herein. Both sexes of Protonyssus have blade-like setae $m G$ on genua II, males have well-developed interlobar membrane, and females have welldeveloped hysteronotal shields, and epigynum encompassing setae $4 a, g$, and genital papillae.

\section{Protonyssus mironovi Hernandes and Pedroso sp. nov.} (Figures 1-3)

Type material

Holotype male, 9 male and 14 female paratypes ex Psittacara leucophthalmus (Statius Müller, 1776) (Psittaciformes: Psittacidae), 9 March 2010, Faz. Mt. D'Este, Campinas, SP, Brazil, $22^{\circ} 49^{\prime} \mathrm{S} 47^{\circ} 02^{\prime} \mathrm{W}$, D. Vilas Boas-Filho coll. (\#684).
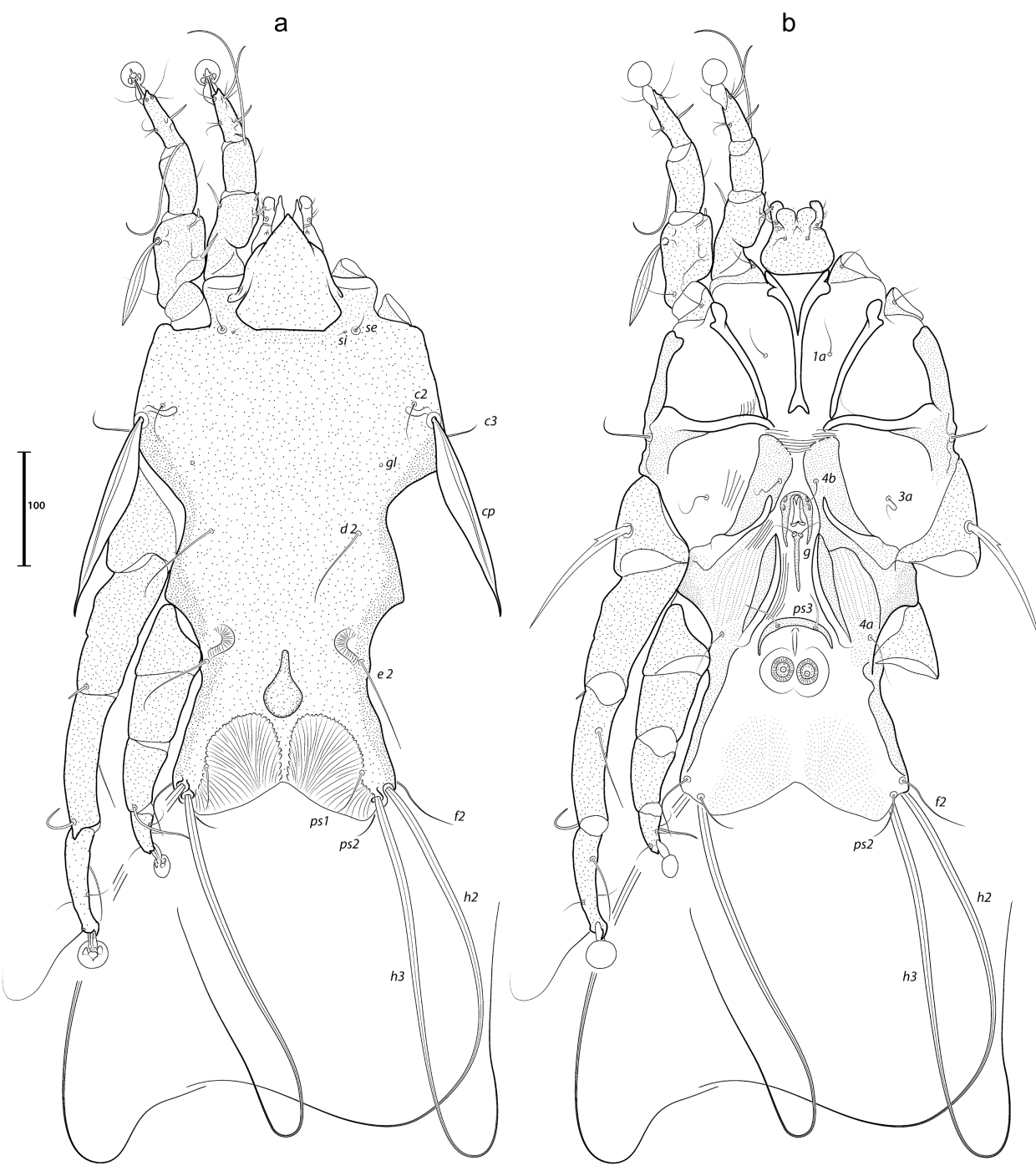

\section{Type deposition}

Holotype and paratypes DZUnesp-RC; paratypes at ZISP, UMMZ, USNM, and DZSJRP.

Male (holotype, range for 8 paratypes in parentheses). Anterior end of idiosoma with triangular rostral projection (Figure 1(a)). Idiosoma length from anterior end of prodorsal shield to bases of setae h3 507 (466-516), greatest width 267 (243-268). Setae se separated by 116 (108-119). Prodorsal, scapular, humeral, and hysteronotal shields fused, covering almost entire idiosoma dorsally. Humeral setae $c p$ blade-like, 159 long (137-155), 22 wide (14-24); setae c3 short setiform. Opisthosomal lobes narrow, slightly divergent posteriorly, terminal cleft very wide, with narrow and long median extension reaching posterior margins of lobes, distance between setae $h 3167$ (158-174). The entire terminal cleft occupied by interlobar membrane, free margin of this membrane outlines medially a blunt-angular incision and laterally a pair of shallow convexities. Supranal concavity well-developed, closed, shaped as a teardrop or wide-based pear. Distances between hysteronotal setal rows: c2-d2 108 (102-114), d2-e2 112 (94-115), e2-h3 118 (101-120).

Coxal fields III open in anteromedian angle, anterior ends of epimerites IIla wide. Coxal fields IV sclerotized. Genital apparatus narrow, 26 long (22-40), genital apodemes fused into narrow arch about 52 long (45-52) (Figure 1(b)). Genital shield represented by narrow longitudinal sclerite bearing setae $g$ in anterior end. Adanal shield bow-shaped, bearing setae ps3. Setae $4 b$ anterior to $3 a$. Distances between ventral setal rows: $4 b-g 47$ (39-48), $g-p s$ 381 (71-82). 

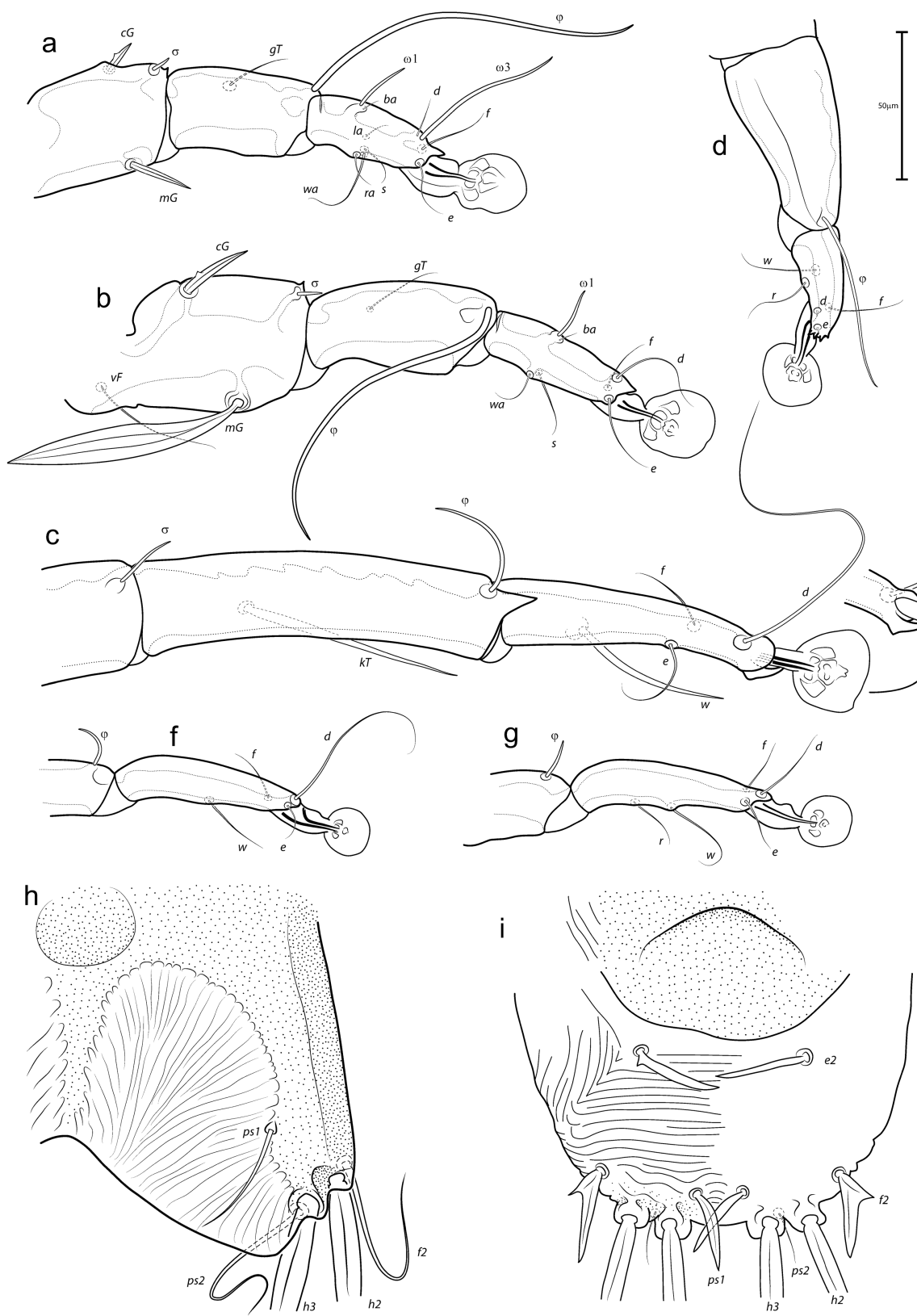

Figure 2. Protonyssus mironovi sp. nov. A-D, F, G - dorsal view of leg segments, E ventral. A-C - Femorogenu, tibia and tarsus of legs I-III of male; D - tibia and tarsus IV of male; $\mathrm{E}$ - distal part of tarsus III of male; F-G - distal part of tibia and tarsus III-IV of female. H-I - dorsal view of opisthosoma of male (H) and female (I).

Setae $m G$ of femorogenua II lanceolate, 79 long (60-79), 10 (79) wide; setae $C G$ II spine-like. Legs III and IV with tarsi extending beyond the level of lobar apices. Setae $s R$ of trochanters III thickened in basal part, with small basal spine. Tarsus III with apical hook-shaped process (Figure 2(c)). Tarsus IV with apical extension bearing three to four small teeth (Figure 2(d)). Legs III (femorogenu, tibia, and tarsus excluding pretarsus): 127 (98-123), 113 (98-119), 94 (87-101), respectively. Legs IV (femorogenu, tibia, tarsus; ambulacral stalk and pretarsus not included): 70 (48-73), 58 (50-66), 37 (34-38), respectively.

Female (range for 8 paratypes). Anterior end of idiosoma with rostral projection as in the male. Idiosomal length 444-468, greatest width 175-195. Prodorsal shield 89-96 in length along median line, 55-66 in width at posterior margin; setae se separated by 85-93; posterior part of prodorsal (at level of scapular setae si and se) shield touching hysteronotal shield, this latter shield having a long median sclerotized ridge, length of hysteronotal shield along median line 288-305 (from the level of scapular setae to posterior margin at level anterior to setae e2), greatest width 133-145 (Figure 3(a)); hysteronotal area posterior to setae $e 2$ with striated tegument. Humeral setae $c p$ large, blade-like with gradually thin apex and smooth margins, 167-208 long, 8-14 wide; setae $d 2$ thick setiform, 60-71 long; setae e2 thick setiform, 27-43 long, setae $f 2$ with a basal additional spine, 30-37 long; setae $p s 1$ thick, setiform, 26-35 long. Distances between hysteronotal setae and setal rows: $c 2-d 2$ 132-150, d2-e2 91-100, e2-h2 53-61, h2-h2 57-62. Epigynum as elongated arch, 62-67 long, 79-88 wide; sclerotized apodemes of oviporus extending to mid-level of trochanters III (Figure 3(b)).

Femorogenua I, II with small lateroapical spine, setae cG II blade-like without additional basal spine, setae $m G \|$ as in the male; setae $s R$ of trochanter III thickened, with small basal spine, 52-59 long. Tibiae III, IV greatly elongated.

\section{Differential diagnosis}

The new species, Protonyssus mironovi sp. n., is close to $P$. integrifolius (Trouessart, 1885) in having setae $c p$ smooth in both sexes, the terminal cleft with a median incision posterior to the supranal concavity (lobes "M-shaped") in males, and the median ridge of hysteronotal shield running almost the entire length in females. Protonyssus mironovi sp. $\mathrm{n}$. is distinguished from $P$. integrifolius in having setae $e 2$ and $d 2$ relatively shorter - 

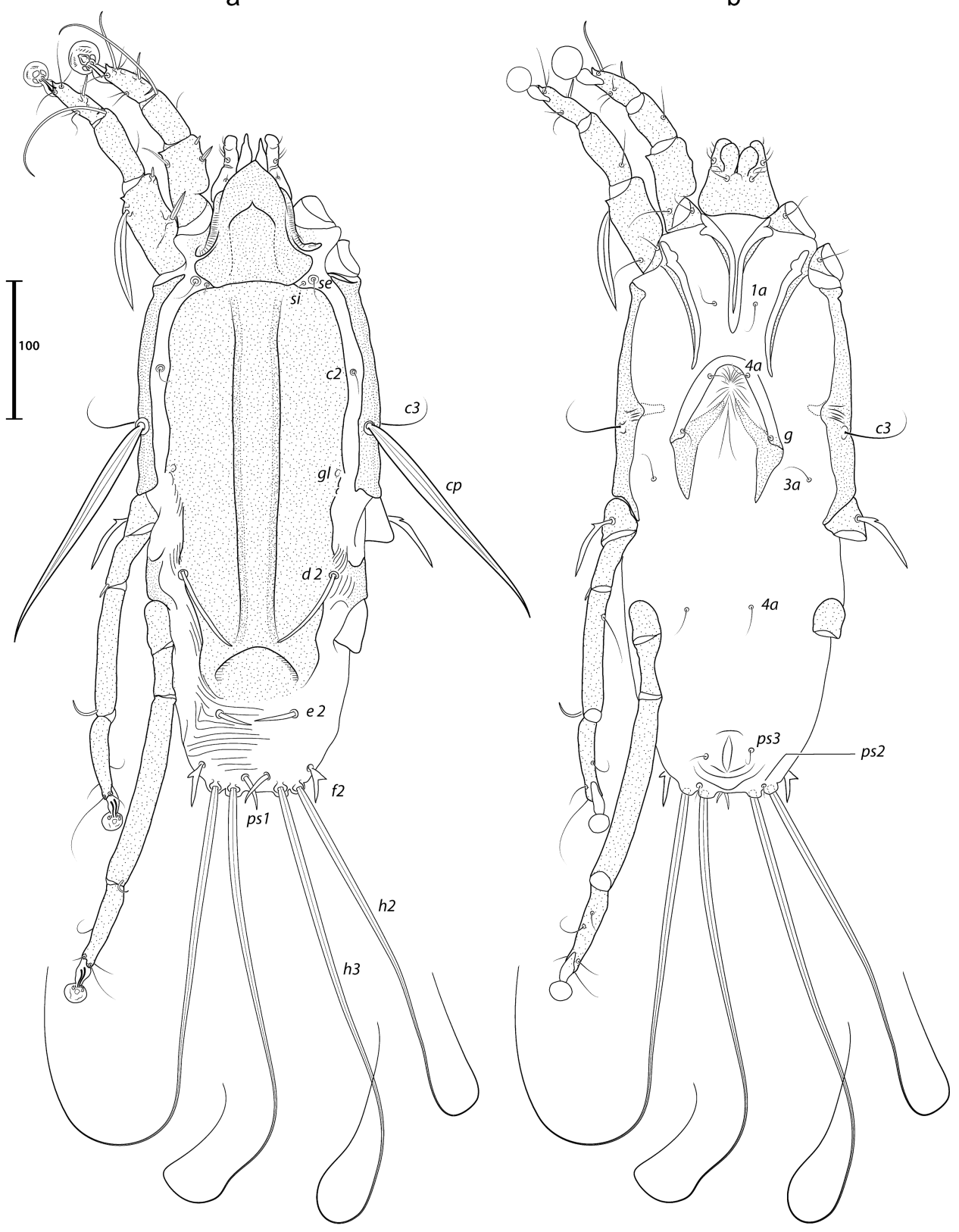

Figure 3. Protonyssus mironovi sp. nov., female. A - dorsal view, B - ventral view.

e2 24-30 $\mu \mathrm{m}$, reaching about halfway to bases of $f 2$; and seta $d 2$ not reaching the margins of the semicircular fold on the posterior part of the hysteronotal shield. In females of $P$. integrifolius setae $e 2$ are about $40 \mu \mathrm{m}$ and reach the bases of $f 2$; seta $d 2$ surpass the semicircular fold on the posterior part of the hysteronotal shield.

\section{Etymology}

The specific name is given after Dr. Sergey V. Mironov (Zoological Institute, Russian Academy of Sciences, St. Petersburg, Russia), the world expert of feather mites, in recognition to his efforts to the systematics of feather mites.

Protonyssus athoracicus Hernandes and Pedroso sp. nov. (Figures 4-6)

\section{Type material}

Holotype male, 6 male and 5 female paratypes ex Brotogeris chiriri (Vieillot, 1818) (Psittaciformes: Psittacidae), October, 2013, Pedreira, SP, Brazil, $22^{\circ} 44^{\prime}$ S $46^{\circ} 54^{\prime}$ W, D. Vilas Boas-Filho coll. (\# 1113).

\section{Type deposition}

Holotype and paratypes at DZUnesp-RC; paratypes at ZISP and UMMZ.

Male (holotype, range for 6 paratypes in parentheses). Anterior end of idiosoma with short and rounded rostral projection (Figure 4(a)). Idiosoma length from anterior end of prodorsal shield to bases of setae $h 3368$ (353-377), greatest width 185 (171-187). Setae se separated by 82 (76-81). Prodorsal, scapular, humeral, and hysteronotal shields fused, covering almost entire idiosoma dorsally. Humeral setae $c p$ blade-like, 151 long (128170), 22 wide (13-25); setae $c 3$ short setiform. Opisthosomal lobes narrow, slightly divergent posteriorly, terminal cleft semicircular, distance between setae h3 104 (97-103). Whole terminal cleft occupied by interlobar membrane, free margin of membrane concave, almost semicircular, with two small and acute terminal extensions near each lobar apex. Supranal concavity well-developed, closed, slightly enlarged posteriorly. Distances between hysteronotal setal rows: $c 2-d 295$ (93-100), d2-e2 70 (74-82), e2-h3 81 (69-75).

Coxal fields III open in anteromedian angle, anterior ends of epimerites Illa wide (Figure 4(b)). Epimerite Illa short, not reaching 

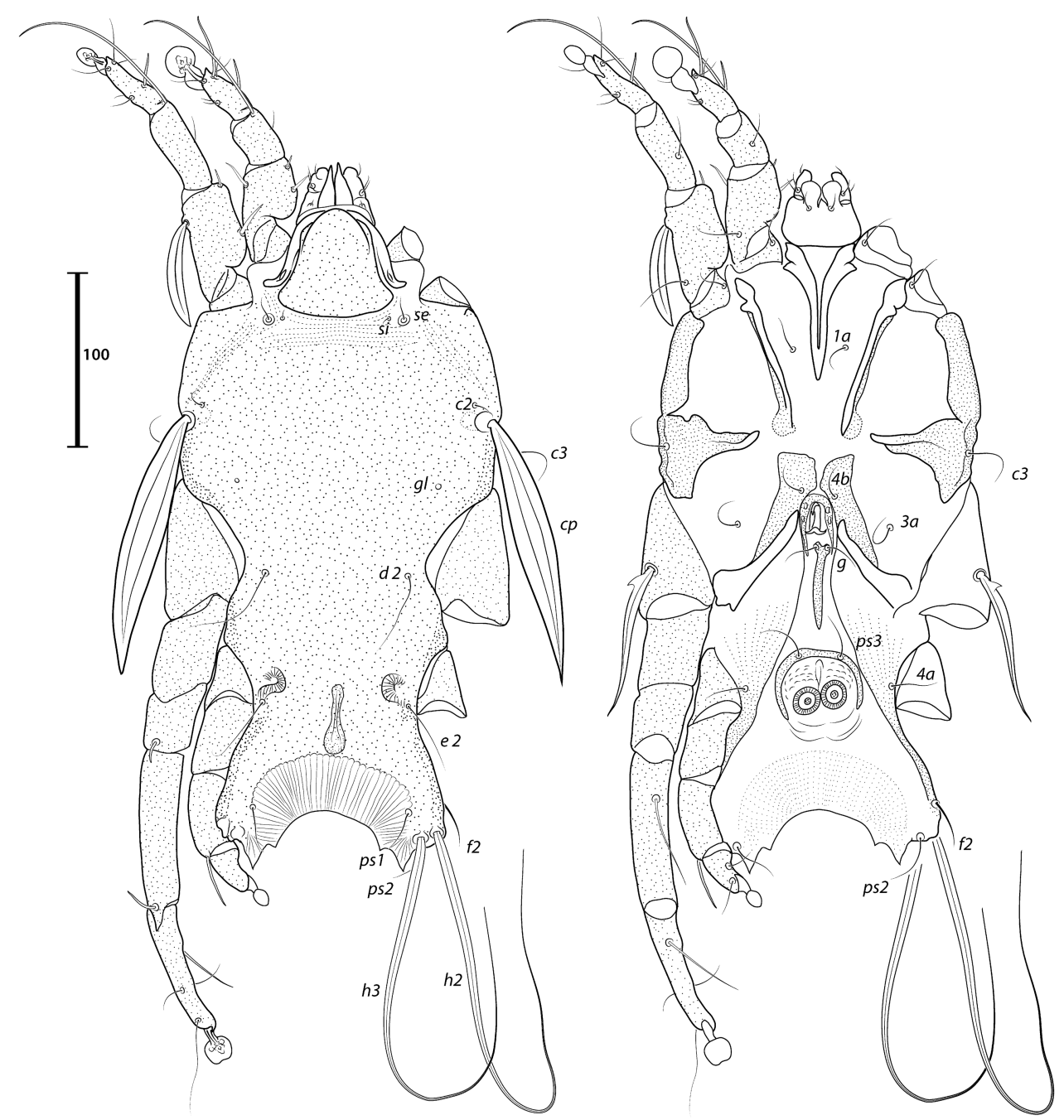

Figure 4. Protonyssus athoracicus sp. nov., male. A - dorsal view, B - ventral view.

posterior extremities of epimerites II. Coxal fields IV sclerotized. Genital apparatus narrow, 26 long (21-30); genital apodemes fused into narrow arch about 33 long (31-38). Genital shield represented by narrow longitudinal sclerite bearing setae $g$ in anterior end. Adanal shield bow-shaped, bearing setae ps3. Setae $4 b$ anterior to $3 a$. Distances between ventral setal rows: 4b-g 31 (29-33), g-ps3 63 (58-63).

Setae $m G$ of femorogenua II blade-like, 65 long (58-70), 10 (513) wide; setae $C G$ II blade-like, with a small spine basally. Legs IV with tarsus extending beyond level of lobar. Setae $s R$ of trochanters III thickened, with basal spine. Tarsus III with apical hookshaped process (Figure 6(c)). Tarsus IV with apical extension bearing three to four small teeth (Figure 6(d)). Legs III (femorogenu, tibia, and tarsus excluding pretarsus): 82 (74-84), 89 (8488), 77 (73-84), respectively. Legs IV (femorogenu, tibia, and tarsus excluding pretarsus): 41 (38-41), 43 (37-43), 27 (25-34), respectively.

Female (range for 5 paratypes). Anterior end of idiosoma with very short rounded extension. Idiosomal length 348-370, greatest width 143-155. Prodorsal shield 52-63 in length along median line, $35-43$ in width at posterior margin; setae se separated by 64-68; posterior part of prodorsal (posterior to scapular setae si and se) shield touching hysteronotal shield, and having long median sclerotized ridge, length of hysteronotal shield along median line 240-255, greatest width 89-98 (Figure 5(a)); area surrounding and posterior to setae e2 with striated tegument. Humeral setae $c p$ large, blade-like with gradually thin apex and smooth margins, 136-156 long, 7-11 wide; setae $d 2$ very thick setiform, 62-73 long; setae e2 thick setiform, 24-30 long, setae f2 with a basal additional spine, 21-34 long; setae ps1 setiform, 19-32 long. Distances between hysteronotal setae and setal rows: c2-d2 99-107, d2-e2 81-88, e2-h2 42-47, h2-h2 47-52. Epigynum as elongated arch, 49-55 long, 64-74 wide; sclerotized apodemes of oviporus extending to mid-level of trochanters III (Figure 5(b)).

Femorogenua I, II without small lateroapical spine, setae cG II thickened blade-like, setae $m G$ II slightly thinner than in the male; setae $s R$ of trochanter III thickened, with small basal spine, 34-45 long.

\section{Differential diagnosis}

Protonyssus athoracicus sp. nov. is most similar to $P$. larva by the semicircular shape of the male opisthosomal lobes. It differs from the latter species most noticeably by the females, which lack the transverse rib-like extensions on the median groove of the hysteronotal shield. Females of $P$. larva have 7-8 transverse rib-like protrusions on each side of the median groove (see Gaud and Atyeo 1996, p. 25, Figure 6(f)). 


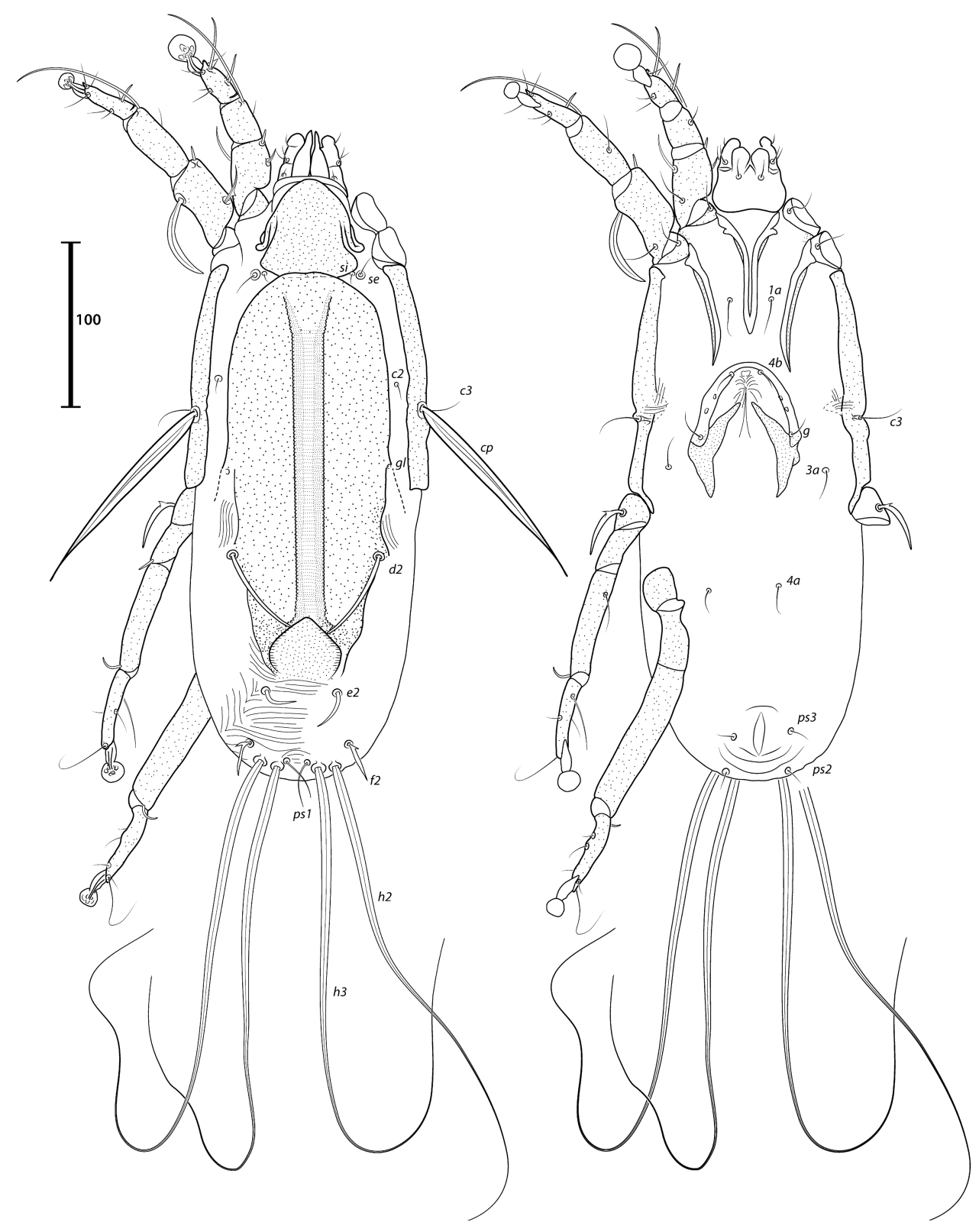

Figure 5. Protonyssus athoracicus sp. nov., female. A - dorsal view, B - ventral view.

\section{Etymology}

Combining of $a$ (without, G.) and thorax ( $\theta \dot{\omega} p a \xi$, thorax, rib cage, $\mathrm{G}$.), referring to the absence of the rib-like lateral projections of the longitudinal median ridge in females.

\section{Key to Protonyssus species}

1. In males, terminal cleft roughly semicircular; in females, hysteronotal shield with or without a median ridge 2

1'. In males, terminal cleft M-shaped because of a long and narrow median extension; in females, hysteronotal shield with a median ridge on dorsal shields 4

2. In females, median longitudinal ridge of hysteronotal shield with 7-8 transverse ribs on each side (see Gaud and Atyeo 1996, p. 25, Figure 6(f)) P. larva (Trouessart 1885)

2 '. In females, median longitudinal ridge, if present, without transverse ribs

3. In both sexes, seta $c p$ simple, setiform; in females, hysteronotal shield without median ridge P. brevis (Trouessart, 1885)

3'. In box sexes, setae $c p$ expanded laterally, blade-like; in females, hysteronotal shield with a median ridge

P. athoracicus sp. nov.

4. In both sexes, seta $c p$ with inner margin indented (serrated) ... P. proctorae Trouessart 1885 (Mironov et al. 2005)

4 '. In both sexes, seta $c p$ with both margins smooth 5

5. In females, setae $e 2$ about $40 \mu \mathrm{m}$ long, reaching bases of setae f2; setae $d 2$ extending to midlevel of semicircular fold on the posterior part of hysteronotal shield P. integrifolius)

5 '. In females, setae e2 24-30 $\mathrm{mm}$ long; setae $d 2$ reaching the anterior margin of the semicircular fold on the posterior part of hysteronotal shield P. mironovi sp. nov.

\section{Acknowledgements}

To David Vilas Boas-Filho for collecting the dead bird specimens. To Dr Mark Judson (Muséum National d'Histoire Naturelle, Paris, France) for allowing $\mathrm{FAH}$ to examine type specimens in the Trouessart Collection. To three anonymous reviewers for their 


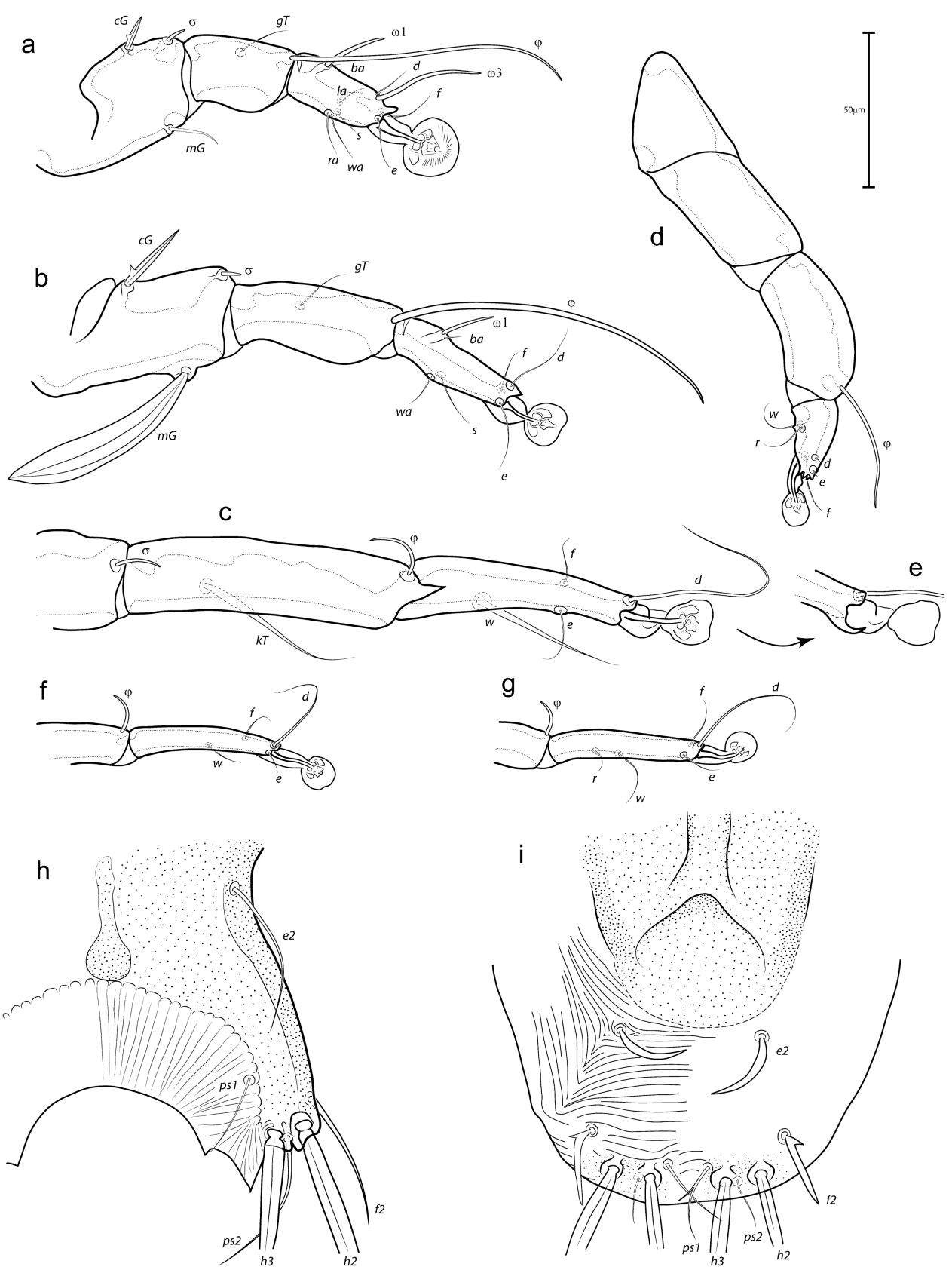

Figure 6. Protonyssus athoracicus sp. nov. A-D, F, G dorsal view of leg segments, E ventral. A-C - Femorogenu, tibia and tarsus of legs I-III of male; D - leg IV of male; E - distal part of tarsus III of male; F-G - distal part of tibia and tarsus III-IV of female. $\mathrm{H}-\mathrm{I}$ - dorsal view of opisthosoma of male (H) and female (I).

invaluable suggestions. This study was supported by the FAPESPSão Paulo Research Foundation (2011/50145-0).

\section{Funding}

This work was supported by the Fundação de Amparo à Pesquisa do Estado de São Paulo [2011/50145-0].

\section{References}

Albuquerque DAD, Brener B, Menna-Barreto RFS, Brun SF. 2012. The first identification of Nymphicilichus perezae Mironov and Galloway, 2002 in cockatiels in Brazil and the first record of Psittophagus sp. Gaud and Atyeo, 1996 and cf. Dubininia sp. Vassilev, 1958 in cockatiels (Nymphicus hollandicus Kerr, 1792). Parasitology International. 61:572-578.

Atyeo WT, Gaud J. 1966. The chaetotaxy of sarcoptiform feather mites (Acarina: Analgoidea). Journal of the Kansas Entomological Society. 39:337-346.
Dabert J, Badek A, Skoracki M. 2007. New feather mite species (Acari, Astigmata) from the Sulphur-crested Cockatoo Cacatua galerita and Yellow-crested Cockatoo C. sulphurea (Psittaciformes, Cacatuidae). Acta Parasitologica. 52:250-267.

Dabert J, Mironov SV. 1999. Origin and evolution of feather mites (Astigmata). Experimental and Applied Acarology. 23:437-454.

Enout AMJ, Lobato DNC, Diniz FC, Antonini Y. 2012. Chewing lice (Insecta, Phthiraptera) and feather mites (Acari, Astigmata) associated with birds of the Cerrado in Central Brazil. Parasitology Research. 111:1731-1742.

Gaud J. 1980. Acariens Sarcoptiformes Plumicoles Parasites sur les oiseaux Psittaciformes, Strigiformes et Caprimulgiformes en Afrique. Musée Royal de L'Afrique Centrale - Tervuren, Belgique Annales - Sciences Zoologiques. 230:1-105.

Gaud J, Atyeo WT. 1981. La famille Xolalgidae, Dubinin, nouveau statut (Sarcoptiformes plumicoles, Analgoidea). I. Sous-famille Ingrassiinae, n. sub. fam. Acarologia. 22:63-79.

Gaud J, Atyeo WT. 1996. Feather mites of the World (Acarina, Astigmata): the supraspecific taxa. Musée Royal de I'Afrique 
Centrale, Annales, Sciences Zoologiques. 277:1-193(Pt. 1, text) 1-436 (Pt. 2, illustrations).

Griffiths DA, Atyeo WT, Norton RA, Lynch CA. 1990. The idiosomal chaetotaxy of astigmatid mites. Journal of Zoology. 220:1-32.

Hernandes FA. 2014. The feather mites of nightjars (Aves: Caprimulgidae), with descriptions of two new species from Brazi (Acari: Xolalgidae, Gabuciniidae). Folia Parasitologica. 61:173-181.

Hernandes FA, Mironov SV. 2015. The feather mites of the hoatzin Opisthocomus hoazin (Müller) (Aves: Opisthocomiformes), with the description of two new genera and six new species (Acari: Analgoidea, Pterolichoidea). Zootaxa. 4034:401-444.

Hernandes FA, Valim MP, Pedroso LGA. 2015. New records of feather mites (Acari: Astigmata) from Pelecaniformes (Aves) in Brazil. Acarina. 23:81-84.

Krantz GW, Walter DE. 2009. A manual of acarology. 3rd ed. Lubbock, TX: Texas Tech University Press; p. 807.

Mironov SV. 2004. Phylogeny of the feather mite family Xolalgidae (Astigmata: Analgoidea) and coevolutionary trends with non-passerine birds. Phytophaga. 24:433-449.

Mironov SV, Proctor HC. 2008. The probable association of feather mites of the genus Ingrassia (Analgoidea: xolalgidae) with the blue penguin Eudyptula minor (Aves: Sphenisciformes) in Australia. The Journal of Parasitology. 94:1243-1248.

Mironov SV, Hernandes FA. 2014. Two new species of the feather mite genus Analloptes (Trouessart, 1885) (Acariformes: Astigmata: Xolalgidae) from passerines (Aves: Passeriformes) in Brazil. Zootaxa. 3889:589-600.
Mironov SV, Dabert J, Ehrnsberger R. 2005. Six new feather mite species (Acari: Astigmata) from the carolina parakeet Conuropsis carolinensis (Psittaciformes: Psittacidae), an extinct parrot of North America. Journal of Natural History. 39:2257-2278.

Norton R. 1998. Morphological evidence for the evolutionary origin of Astigmata (Acari: Acariformes). Experimental and Applied Acarology. 22:559-594.

Pedroso LGA, Hernandes FA, Mironov SV. 2015. New records of feather mites (Acari: Astigmata) from Brazil, with description of a new species from the Black Vulture (Aves: Cathartidae). International Journal of Acarology. 41:181-188.

Silva HM, Hernandes FA, Pichorim M. 2015. Feather mites (Acari, Astigmata) associated with birds in an Atlantic Forest fragment in Northeastern Brazil. Brazilian Journal of Biology. 75:726-735.

Trouessart EL. 1885. Note sur la classification des Analgésiens et diagnoses d'espèces et de genres nouveaux. Bulletin de la Société d'études scientifiques d'Angers. 14:46-89.

Trouessart EL. 1916. Révision des genres de la sous-famille des Analgesinae, ou Sarcoptides plumicoles. Bulletin de la Société Zoologique de France. 40:207-223.

Valdebenito JO, Moreno L, Landaeta-Aqueveque C, Kinsella JM, Mironov S, Cicchino A, Troncoso I, González-Acuña D. 2015. Gastrointestinal and external parasites of Enicognathus ferrugineus and Enicognathus leptorhynchus (Aves, Psittacidae) in Chile. Brazilian Journal of Veterinary Parasitology. 24:422-431.

Valim MP, Hernandes FA, Proctor HC. 2011. Feather mites of Brazil (Acari: Astigmata: Analgoidea and Pterolichoidea). International Journal of Acarology. 37:293-324. 